\title{
CD3E wt Allele
}

National Cancer Institute

\section{Source}

National Cancer Institute. CD3E wt Allele. NCI Thesaurus. Code C52022.

Human CD3E wild-type allele is located within $11 \mathrm{q} 23$ and is approximately $11 \mathrm{~kb}$ in length.

This allele, which encodes T-cell surface glycoprotein CD3 epsilon chain protein, is

involved in signal transduction essential for T cell receptor signaling and synapse

formation. Certain allelic variants of the CD3E gene are associated with T cell immunodeficiency. 